\title{
PENGARUH MODEL PEMBELAJARAN SNOWBALL THROWING TERHADAP KEMAMPUAN KERJASAMA KELOMPOK B GUGUS VI KECAMATAN BULELENG
}

\author{
Nur Izza Avcarina ${ }^{1}$, Ketut Pudjawan², Putu Rahayu Ujianti ${ }^{3}$ \\ 1,3 Jurusan Pendidikan Dasar \\ ${ }^{2}$ Jurusan IImu Pendidikan, Psikologi dan Bimbingan \\ Universitas Pendidikan Ganesha \\ Singaraja, Indonesia \\ e-mail: izza.afcarina37@gmail.com¹, ketut.pudjawan@undiksha.ac.id¹, \\ puturahayuujianti@undiksha.ac.id ${ }^{2}$
}

\begin{abstract}
Abstrak
Penelitian ini bertujuan untuk mengetahui pengaruh yang signifikan model pembelajaran Snowball Throwing terhadap kemampuan kerjasama pada anak taman kanak-kanak kelompok B di gugus VI Kecamatan Buleleng tahun pelajaran 2018/2019. Penelitian ini termasuk jenis penelitian eksperimen semu yang menggunakan desain Non Equivalent Post test Control Group Design. Populasi dalam penelitian ini adalah seluruh anak kelompok B Taman Kanak-kanak Gugus VI Tahun Pelajaran 2018/2019 yang berjumlah 385 anak.Teknik pengambilan sampel yang digunakan adalah Clauster Sampling. Sampel penelitian ini adalah 22 anak di kelompok B TK AthThooriq sebagai kelompok eksperimen yang diberikan pembelajaran dengan model pembelajaran Snowball Throwing dan 20 anak di kelompok B TK Aisyiyah Bustanul Athfal sebagai kelompok kontrol yang diberikan model pembelajaran konvensional. Data penelitian ini dikumpulkan dengan menggunakan metode observasi dengan instrumen berupa rubrik kemampuan kerjasama.Kemudian data yang terkumpul di analisis menggunakan uji prasyarat (analisis statistik inferensial).Dari uji normalitas dan homogenitas varians, diketahui bahwa sampel berdistribusi normal, dan varian populasi bersifat homogen maka untuk menguji hipotesis digunakan uji-t dengan taraf signifikansi $5 \%$. Hasil perhitungan uji-t menemukan bahwa hasil thitung $=10,12$ dan ttabel dengan $\mathrm{dk}=(22+20-2=40)$ dengan taraf signifikasi $5 \%=2,024$ dengan demikian thitung $>$ ttabel $=10,12>2,024$, maka HO ditolak dan Ha diterima. Maka dapat disimpulkan bahwa terdapat pengaruh yang signifikan model pembelajaran Snowball Throwing terhadap kemampuan kerjasama pada anak taman kanak-kanak kelompok B di gugus VI Kecamatan Buleleng tahun pelajaran 2018/2019.
\end{abstract}

Kata Kunci: kemampuan kerjasama, konvensional, Snowball Throwing, anak usia dini

Abstract
This study aims to determine the significant effect of Snowball Throwing learning model for children
teamwork skill of kindergarten in group B VI cluster of Buleleng Subdistrict in $2018 / 2019$. This
study included type of quasi-experimental research that used a Non Equivalent Post-test Control
Group Design. The population in this study were all children in kindergarten group B VI in
academic year $2018 / 2019$ with 385 children. The sampling technique used was Cluster Sampling.
The sample of this study were 22 children in group B of Ath-Thooriq Kindergarten as the
experimental group who were given the Snowball Throwing learning model and 20 children in
group B at Aisyiyah Bustanul Athfal kindergarten as the control group who were given the
conventional learning models. The data of this study were collected using observation methods
with instruments in the form of collaboration ability rubrics. Then, the collected data was analyzed 
using a prerequisite test (inferential statistical analysis). From the normality and homogeneity test of variance, it is known that the sample was distributed normally, and the population variant was homogeneous. So to test the hypothesis, t-test was used with a significance level of $5 \%$. The results of the $\mathrm{t}$-test calculation found that the results of $\mathrm{t}$-count $=10.12$ and $\mathrm{t}$ table $\mathrm{dk}=(22+20-2$ $=40$ ) and a significance level of $5 \%=2.024$ thus tcount $>$ ttable $=10.12>2.024$, then $\mathrm{HO}$ is rejected and $\mathrm{Ha}$ was accepted. Then it can be concluded that there is a significant effect of Snowball Throwing learning model on the ability of teamwork skill for children in kindergarten at group $B$ in cluster VI of Buleleng Subdistrict in 2018/2019.

Keywords: teamwork ability, conventional, snowball throwing, young children

\section{PENDAHULUAN}

Anak usia dini adalah individu yang berada pada proses perkembangan yang pesat dan fundamental untuk kehidupan selanjutnya. Pada masa ini anak mengalami masa keemasannya (the golden age) dimana anak mulai peka untuk menerima berbagai macam rangsangan/stimulasi. Selain itu, pada masa ini anak lebih aktif bertanya dan memiliki rasa ingin tahu yang tinggi tentang apa yang dilihat dan di dengarnya. Di masa inilah pendidikan yang diberikan pada anak akan menjadi sebuah dasar pengetahuan anak untuk menuju pendidikan selanjutnya.

Pendidikan anak usia dini merupakan salah satu bentuk penyelenggaraan pendidikan yang menitik beratkan pada peletakan dasar pertumbuhan dan perkembangan anak. Undang-Undang Nomor 20 Tahun 2003 tentang Sistem Pendidikan Nasional Pasal 1 angka 14 menyatakan bahwa, Pendidikan Anak Usia Dini adalah suatu pembinaan yang dikhususkan untuk anak usia sejak lahir sampai dengan 6 tahun yang dilakukan melalui pemberian rangsangan pendidikan untuk membantu pertumbuhan dan perkembangan jasmani dan rohani agar anak memiliki kesiapan yang matang dalam memasuki pendidikan lebih lanjut. Pendidikan anak usia dini merupakan pendidikan untuk memfasilitasi anak dalam masa pertumbuhan dan perkembangan anak secara menyeluruh atau menekankan seluruh aspek perkembangan. Menurut Permendikbud No 137 Tahun 2014 Pasal 10 "lingkup perkembangan sesuai tingkat usia anak meliputi aspek nilai agama dan moral, fisik-motorik, kognitif, bahasa, sosial emosional dan seni".

Salah satu tugas perkembangan yang harus distimulasi adalah perkembangan sosial dengan mengenalkan aturan-aturan yang berlaku pada lingkungan anak. Menurut Hurlock (dalam Nugraha, 2015:1.18) perkembangan sosial merupakan "perolehan kemampuan berperilaku yang sesuai dengan tuntutan sosial". Perkembangan sosial berhubungan dengan perilaku anak dalam menyesuaikan diri dengan aturan-aturan masyarakat dan lingkungannya. Bagi anak usia dini, kegiatan bermain menjadikan fungsi sosial mereka semakin berkembang (Mulyasa, 2017:31).

Perkembangan sosial pada anak terdapat beberapa jenis, salah satunya yaitu kemampuan kerjasama.Kemampuan kerjasama yang merupakan salah satu komponen dari kemampuan di bidang sosial merupakan hal yang penting untuk dikembangkan dalam diri anak. Pada kemampuan sosial anak usia 5-6 tahun, anak sudah mulai mengenal cara merespon, memberi atau menerima, menolak atau setuju dengan membangun hubungan dengan anak lain, berperilaku sesuai dengan aturan masyarakat, menyesuaikan diri dengan teman baru, dapat memahami peilakunya sendiri, dan paham bahwa setiap perbuatan yang dilakukan selalu ada kosekuensinya.

Menurut (Susanto, 2012:40) "Perkembangan sosial merupakan pencapaian kematangan dalam hubungan sosial". Perkembangan sosial merupakan proses pembentukan social self (pribadi dalam masyarakat), yakni pribadi dalam keluarga, budaya dan seterusnya. Perkembangan sosial merupakan perolehan kemampuan bertingkah laku sesuai dengan tuntutan sosial. "Sosialisasi adalah kemampuan bertingkah laku sesuai dengan norma, nilai atau harapan sosial" (Nugraha, 2015). Sosial adalah segala perilaku manusia yang menggambarkan hubungan non individuallisme.

Berhubungan dengan perkembangan sosial anak ada beberapa aspek yang berhubungan dengan perkembangan sosial anak dari studi Carsaro (dalam Mayar, 2013) menyatakan, Disaat anak berinteraksi dengan kelompok teman sebaya, anak-anak prasekolah saling berbagi (sharing) 
dalam dua hal. Pertama adalah berupa partisipasi sosial (sosial participation) yakni keterlibatan anak dalam aktivitas bermain bersama atau berupaya mengikuti kegiatan kelompok teman yang sedang berlangsung. Kedua adalah berupa perlindungan terhadap kawasan pergaulan kelompok (the protection of interactive space) yakni kecenderungan anak yang terlibat dalam suatu kegiatan bermain yang sedang berlangsung untuk menolak upaya atau gangguan dari anak lain yang sedang berpatisipasi.

Manusia sebagai makhluk sosial tidak dapat dipisahkan dari kelompoknya dan setiap orang didunia ini tidak ada yang dapat berdiri sendiri melakukan segala aktivitas untuk memenuhi kebutuhannya, tanpa bantuan orang lain. Begitupun anak, dalam aktivitas usaha setiap anak selalu membutuhkan kehadiran dan peran orang lain. Salah satu ciri khas perkembangan sosial yang berkembang adalah kemampuan kerjasama.

Kerjasama adalah bentuk proses sosial, di mana di dalamnya terdapat aktifitas tertentu yang ditunjukkan untuk mencapai tujuan bersama dengan saling membantu dan saling memahami terhadap aktivitas masing-masing. Sejalan dengan Yudha M. Saputra (dalam Distiara, 2015) di dalam bukunya menjelaskan bahwa kerjasama (cooperative) adalah sebuah kondisi dimana satu orang dengan orang lainnya saling mendekat untuk mengurus sebuah kepentingan dan tujuan bersama-sama.

Surgent (dalam Adistyasari, 2013) juga menyatakan bahwa kerjasama adalah suatu bentuk interaksi sosial dimana tujuan anggota kelompok yang satu berkaitan erat dengan tujuan anggota kelompok yang lain atau tujuan kelompok secara keseluruhan sehingga seseorang individu hanya dapat memperoleh tujuan bila individu lain juga mencapai tujuan.

Kemampuan kerjasama bertujuan untuk mengembangkan kreativitas anak dalam berkelompok dan bermain bersama dengan teman-temanya.Sejalan dengan Catron dan Allen (dalam Sujiono, 2009:63) menyatakan bahwa "melalui bermain anak dapat belajar bekerjasama". Ramani (dalam rohmawati, 2017) menjelaskan bahwa kerjasama merupakan sikap mau bekerja dengan orang lain atau kelompok. Aktivitas bekerjasama juga dapat melatih kegiatan dalam suatu pemecahan masalah dengan teman sebaya secara kooperatif, sehingga dapat memainkan peran sentral dalam perkembangan kognitif dan sosial anak. Kemampuan kerjasama pada masingmasing anak dapat menciptakan sikap toleransi, tindakan menghargai pendapat, sikap dan tindakan orang lain yang berbeda dengan dirinya. Pernyataan tersebut menunjukkan bahwa usia 5 -6 tahun anak seharusnya sudah bisa bekerjasama dengan temannya.

Suyanto (dalam Fauzidin, 2016) menyebutkan bahwa dalam kerjasama anak usia dini harus ada empat elemen dasar yaitu: saling ketergantungan yang saling menguntungkan pada anak daam melakukan usaha bersama-sama, adanya interaksi langsung antara anak dalam satu kelompok, masing-masing anak mempunyai tanggung jawab untuk bisa menguasai materi yang diajarkan, menggunakan kemampuan interpersonal dan kelompok kecil secara tepat yang dimiliki setiap anak.

Menurut Mulyasa (2017:73) "kerjasama adalah perilaku yang didasarkan pada upaya menjadikan dirinya mampu menjalin hubungan dengan orang lain dalam melaksanakan tindakan dan pekerjaan". Yusuf (2012:66) menyatakan, Anak mulai memiliki kesanggupan menyesuaikan diri dari sikap berpusat kepada diri sendiri (egosentris) kepada sikap bekerjasama (kooperatif) atau sosiosentris (mau memperhatikan kepentingan orang lain). Anak cenderung menginginkan kegiatan-kegiatan yang berhubungan dengan teman sebaya, dan semakin kuat keinginannya untuk diterima menjadi anggota kelompok (gang), dan merasa tidak senang apabila tidak diterima oleh kelompoknya.

Menurut Tedjasaputra (2001:88) "indikator dalam kemampuan kerjasama adalah: 1) anak dapat membina dan mempertahankan hubungan dengan teman. 2) anak mau berbagi dengan teman lain. 3) anak mau menghadapi masalah bersama-sama. 4) mau menunggu giliran. 5) belajar mengendalikan diri". Menurut Permendikbud No 137 Tahun 2014 "indikator kerjasama adalah: 1) mengetahui perasaan temannya dan merespon secara wajar. 2) berbagi dengan orang lain. 3) menghargai hak dan pendapat orang lain. 4) menggunakan cara yang diterima secara sosial dalam menyelesaikan masalah (menggunakan fikiran untuk menyelesaikan masalah). 5) mentaati aturan ". 
Pada kenyataan yang ada di lapangan ternyata kemampuan anak belum menunjukkan kemampuan kerjasama masih rendah, seperti pada saat kegiatan kelompok anak tidak sabar menunggu giliran, tidak menghargai pendapat dan sikap orang lain. Banyak alasan yang melatar belakangi hal tersebut, mulai dari penggunaan model pembelajaran yang monoton, kurangnya variasi media pembelajaran yang digunakan, hal ini terlihat guru masih banyak memanfaatkan papan tulis sebagai media pembelajaran.

Berdasarkan hasil wawancara terhadap guru kelompok B di Taman Kanak-Kanak gugus VI Kecamatan Buleleng, ditemukan bahwa kemampuan dalam kerjasama anak masih rendah dikarenakan anak kurang antusias dalam mengikuti kegiatan kelompok, seperti guru kurang membiasakan bergaul atau berteman dengan teman sebayanya dalam melakukan tugas kelompok, tidak menghargai pendapat dan sikap temannya. Rendahnya kemampuan anak dalam kerjasama disebabkan model pembelajaran yang digunakan guru dalam pembelajaran masih menggunakan model pembelajaran konvensional. Model pembelajaran konvensional yang dimaksudkan adalah model pembelajaran yang biasa diterapkan disekolah dalam pembelajaran sehari-hari seperti model pembelajaran ceramah dan tanya jawab. Sehingga anak cepat bosan mengikuti pembelajaran dikelas dan tidak ada rasa antusias pada anak untuk aktif dalam mengikuti pembelajaran di kelas.

Melihat kurangnya kemampuan kerjasama anak di lapangan, maka diperlukan suatu model pembelajaran yang mendukung agar kemampuan kerjasama anak meningkat. Peneliti ingin menerapkan model pembelajaran Snowball Throwing yang sudah disesuaikan dengan kebutuhan anak dalam pelaksanaan pembelajaran yang berkaitan dengan kerjasama anak, maka diharapkan dengan diterapkanya model pembelajaran Snowball Throwing dapat berpengaruh terhadap kemampuan kerjasama anak kelompok B di Taman Kanak-Kanak gugus VI Kecamatan Buleleng, karena model pembelajaran ini melatih anak untuk aktif dan mau memberikan pengetahuan dengan kegiatan berkelompok. Jadi salah satu model pembelajaran yang bisa diterapkan dan dikembangkan untuk melatih kerjasama anak disekolah adalah model pembelajaran Snowball Throwing.

Hamdayama (dalam Faidho, 2016) menyatakan Secara etimologi Snowball berarti bola salju, sedangkan Throwing artinya melempar. Snowball Throwing dapat diartikan melempar bola salju, dalam pembelajaran Snowball Throwing, bola salju merupakan kertas yang berisi kata atau kalimat yang dibuat oleh anak-anak atau guru kemudian dilempar kepada temanya sendiri untuk dibaca.

Pengajaran Snowball Throwing sangat memberikan kesempatan pada anak untuk aktif dan mau bertukar pengalaman dalam menyelesaikan permasalahan yang muncul dan berlangsung secara lebih interaktif dan menyenangkan. Model pembelajaran ini bertujuan untuk melatih anak memecahkan masalah yang dialami saat proses pembelajaran. Dalam kegiatan pembelajaran dengan menggunakan model pembelajaran Snowball Throwing, anak akan dilatih saling memberikan pengetahuan dengan kegiatan berkelompok, dengan begitu pengalaman yang di peroleh anak secara langsung akan lebih bermakna.

Syahrul (2014) menyatakan, Model pembelajaran Snowball Throwing adalah suatu metode pembelajaran yang diawali dengan membentuk kelompok yang diwakili ketua kelompok untuk mendapat tugas dari guru untuk menyebutkan ciri-ciri gambar yang ada dalam kertas, kemudian masing-masing anak mengambil sebuah gambar lalu kertas (kertas pertanyaan) tersebut dibentuk seperti bola lalu dilempar ke anak lain yang masing-masing anak akan menyebutkan ciri-ciri dari gambar yang di lemparkan oleh lawan kelompoknya maka anak akan menjawab pertanyaan dari bola kertas yang diperoleh, hal tersebut dapat dilakukan dengan bekerjasama terhadap masingmasing kelompok. Kegiatan melempar bola pertanyaan ini akan membuat kelompok menjadi dinamis, karena kegiatan anak tidak hanya berpikir, menulis, bertanya, atau berbicara. Akan tetapi mereka juga melakukan aktivitas fisik yaitu menggulung kertas dan melemparkannya pada anak lain. Dengan demikian, setiap anggota kelompok akan menyiapkan diri karena pada gilirannya mereka harus menjawab pertanyaan dari temannya yang terdapat dalam bola kertas. karena pada saat kelompoknya mendapatkan giliran mereka harus bisa menjawab pertanyaan temannya yang ada terdapat dalam bola kertas tersebut.

Berdasarkan kajian tentang model pembelajaran Snowball Throwing diharapkan mempunyai pengaruh terhadap kemampuan kerjasama anak pada kelompok B gugus VI kecamatan Buleleng. 
Untuk itu peneliti melakukan penelitian eksperimen yang berjudul "Pengaruh model pembelajaran Snowball Throwing terhadap kemampuan kerjasama pada taman kanak-kanak kelompok B Gugus VI Kecamatan Buleleng Tahun Pelajaran 2018/2019. Tujuan penelitian ingin dicapai adalah untuk mengetahui pengaruh yang signifikan model pembelajaran Snowball Throwing terhadap kemampuan kerjasama pada anak taman kanak-kanak kelompok B di gugus VI Kecamatan Buleleng Tahun Pelajaran 2018/2019.

\section{METODE}

Penelitian dilakukan pada Taman Kanak-kanak kelompok B di gugus VI Kecamatan Buleleng Tahun Pelajaran 2018/2019".Penentuan waktu penelitian disesuaikan dengan kalender pendidikan di Taman Kanak-kanak gugus VI Kecamatan Buleleng.Penelitian yang digunakan dalam penelitian ini yaitu penelitian eksperimen.Sugiyono (2010:72) berpendapat bahwa penelitian eksperimen dipergunakan untuk mencari pengaruh dari perlakuan tertentu terhadap kondisi terkendali, eksperimen merupakan penelitian yang dimaksudkan untuk mengetahui ada tidaknya akibat dari treatment pada subjek yang diselidiki.Sehingga pada dasarnya penelitian ini bertujuan untuk mengetahui pengaruh model pembelajaran Snowball Throwing terhadap kemampuan kerjasama pada anak.

Penelitian ini memeberikan perlakuan pada kelompok eksperimen dan membandingkannya dengan kelompok kontrol.Rancangan pada penelitian ini tergolong ke dalam penelitian eksperimen semu (Quasi Eksperimental), karena tidak semua variabel dapat di kontrol secara ketat. Desain penelitian ini menggunakan rancangan Non Equivalent Post tes Control group design. Desain penelitian ini dimulai dengan terlebih dahulu menentukan kelompok yang akan diberikan perlakuan, kemudian kelompok tersebut diberikan perlakuan yang berbeda, setelah itu kedua kelompok sama-sama diberikan tes akhir untuk melihat apakah ada pengaruh dari perlakuan. Menurut Emzir (2014:102) dengan desain ini, baik kelompok eksperimen maupun kelompk kontrol dibandingkan, kendati kelompok tersebut dipilih dan ditempatkan tanpa melalui randomisasi.

Sugiyono (2015: 61) menjelaskan bahwa "Populasi adalah wilayah generalisasi yang terdiri atas objek atau subjek yang mempunyai kualitas dan karakteristik tertentu yang ditetapkan oleh peneliti untuk dipelajari kemudian ditarik kesimpulannya".Populasi yang digunakan dalam penelitian ini adalah seluruh anak pada kelompok B TK gugus VI Kecamatan Buleleng.Populasi yang ada kemudian diuji kesetaraannya dengan menggunakan ANAVA A satu jalur (Koyan, 2012:42). Uji analisis data dari setiap kelompok diambil dari skor kemampuan kognitif yang diperoleh dari keterampilan proses sains. Skor-skor tersebut kemudian dianalisis varian dengan hipotesis sebagai berikut.

Hipotesis:

$\mathrm{H}_{0}=$ Kelompok dalam populasi setara

$\mathrm{H}_{1}=$ Kelompok dalam populasi tidak setara

Jika $\mathrm{F}_{\text {hitung }} \geq \mathrm{F}_{\text {tabel }} \mathrm{H}_{0}$ ditolak $\mathrm{H}_{1}$ diterima sehingga kelompok tidak setara.Jika Fhitung $\leq$ Ftabel $\mathrm{H}_{1}$ ditolak $\mathrm{H}_{0}$ diterima sehingga kelompok setara. Berdasarkan hasil uji kesetaraan menggunakan ANAVA A satu jalur pada taraf signifikansi $5 \%$ diperoleh nilai $F_{\text {hitung }}=1,13 \leq F_{\text {tabel }}=1,59$ dengan $\mathrm{db}_{\mathrm{antar}}=20$ dan $\mathrm{db}_{\text {dalam }}=364$. Sehingga dapat dinyatakan bahwa dalam populasi setara.

Menurut Agung (2014:69) menjeaskan bahwa Sampel adalah sebagian dari populasi yang diambil, yang dianggap mewakili seluruh populasi dan diambil dengan menggunakan teknik tertentu.sampel yang diambil dari populasi harus benar-benar mewakili populasi dari penelitian. Pada penelitian ini, teknik pemilihan sampel kelompok eksperimen dan kelompok kontrol, digunakan teknik sampel Clauster sampling. Menurut Sugiyono (2015:121) "teknik ini digunakan sebagai teknik pengambilan sampel karena individu-individu pada populasi telah terdistribusi kedalam kelas-kelas sehingga tidak memungkinkan untuk melakukan pengacakan (randominasi) terhadap individu-individu dalam populasi".

Dari keseluruhan TK yang ada di gugus VI Kecamatan Buleleng maka dilakukan pengundian nama TK untuk mendapatkan dua sekolah yang akan digunakan penelitian, yaitu kelas kontrol dan kelas eksperimen. Setelah dilakukan pengundian diperoleh hasil dua kelompok kelas yang 
digunakan sebagai sampel penelitian yaitu berjumlah 20 anak di kelompok B2 TK Aisyiyah Bustanul Athfal dan berjumlah 22 anak di kelompok B2 TK Ath-Thooriq.

Data kemampuan kerjasama dalam penelitian ini dikumpulkan dengan menggunakan rubrik.Pedoman tes berupa instrumen berbentuk check-list dengan menggunakan kategori nilai 1,2,3,4.Pengujian validitas instrumen pada penelitian ini menggunakan uji validitas isi. Menurut Candiasa (2011:22) "Validitas isi menyangkut isi dan format instrumen. Isi dan format instrumen harus konsisten dengan definisi variabel dan sampel materi yang akan diukur". Untuk menguji validitas isi, dapat diuji menggunakan Expert Judgement. Hasil uji coba kemudian di analisis dengan menggunakan rumus Gregory, dari analisis tersebut mendapatkan hasil 0,92 yang berarti sangat tinggi.

Metode pengumpulan data dan teknik analisis data dikumpulkan menggunakan uji asumsi (analisis statistik inferensial).Statistik inferensial berfungsi untuk menggeneralisasikan hasil penelitian yang dilakukan pada sampel bagi populasi.Statistik inferensial digunakan untuk menguji hipotesis melalui uji-t yang diawali dengan analisis deskriptif, analisis prasyarat yaitu uji normalitas dan uji homogenitas. Analisis deskriptif yaitu menghitung mean terlebih dahulu kemudian menghitung median dan terakhir menghitung modus. Uji prasyarat analisis menggunakan uji normalitas dan uji homogenitas. Uji normalitas sebaran data dilakukan untuk menyajikan bahwa sampel benar-benar berasal dari populasi yang berdistribusi normal. Uji normalitas sebaran data untuk skor keterampilan proses sains anak pada digunakan analisis Chi-Kuadrat. Kriteria pengujian data berdistribusi normal jika $x^{2}$ hitung $^{2} x^{2}$ tabel dengan taraf signifikansi $5 \%$ dan derajat kebebasan $\mathrm{dk}=(\mathrm{K}-1)$.

Uji homogenitas kedua kelompok digunakan uji Fisher $(F)$.Kriteria pengujian, jika Fhit $\left(n_{1}-1\right.$, $\left.n_{2}-1\right) F_{\text {hit }}>F_{\text {tabel }}$ maka sampel tidak homogen dan jika $F_{\text {hit }}<F_{\text {tabel }}$ maka sampel homogen. Pengujian dilakukan dengan taraf signifikansi $5 \%$ dengan df1 $=\mathrm{k}-1=2-1=1$, dan df2 $=\mathrm{n}-\mathrm{k}=42-2=40$.

Uji hipotesis alternative atau hipotesis kerja Ha yang berbunyi "Terdapat pengaruh yang signifikan model pembelajaran Snowball Throwing terhadap kemampuan kerjasama pada anak taman kanak-kanak kelompok B di gugus VI Kecamatan Buleleng tahun pelajaran 2018/2019. Kriteria pengujian yaitu pada taraf signifikansi $5 \%$ dengan $d k=n 1+n 2-2$, jika harga $t_{\text {hitung }} \leq t_{\text {tabel }}$ maka $\mathrm{H}_{0}$ diterima, dan jika harga $t_{\text {hitung }} \geq \mathrm{t}_{\text {tabel }}$ maka $\mathrm{H}_{0}$ ditolak.

\section{HASIL DAN PEMBAHASAN}

Data hasil post-test kemampuan kerjasama anak kelompok eksperimen di RA Ath-thooriq Singaraja menunjukkan bahwa nilai tertinggi adalah 48 dan nilai terendah adalah 25 . Data rekapitulasi perhitungan skor kemampuan kerjasama anak pada kelompok eksperimen menunjukkan bahwa nilai mean adalah 39 median 37 dan modus 42. Sebaran data kemampuan kerjasama pada kelompok eksperimen dapat dilihat pada tabel 1.

Tabel 1.

Ringkasan Hasil Statistik Kemampuan Kerjasama Kelompok Eksperimen

\begin{tabular}{ll}
\hline \multicolumn{1}{c}{ Statistik Deskriptif } & Hasil Post test Kelompok Eksperimen \\
\hline Mean & 39 \\
Median & 37 \\
Modus & 42 \\
Standar Deviasi & 8,9 \\
Varians & 79,38 \\
\hline
\end{tabular}


Berdasarkan Tabel.1 diketahui bahwa modus lebih besar dari median dan lebih besar dari mean (Mo>Me>M). sehingga kurva berbentuk juling negatif. Mengetahui kualitas variable kemampuankerjasama anak kelompok eksperimen. Skor rata-rata dikonversikan berdasarkan penilaian skala lima. Hasil konversi penilaian skala lia untuk kelompok eksperimen dapat dilihat pada tabel 2.

Tabel 2.

Konversi Skala Lima Hasil Post Test Kelompok Eksperimen

\begin{tabular}{lll}
\hline \multicolumn{1}{c}{ Konversi } & \multicolumn{1}{c}{ Kelas Interval } & \multicolumn{1}{c}{ Klasifikasi/ Predikat } \\
\hline $\mathrm{Mi}+1,5 \mathrm{SDi}$ s/d Mi + 3 SDi & $39-<48$ & Sangat baik \\
$\mathrm{Mi}+0,5 \mathrm{SDi}$ s/d Mi + 1,5 SDi & $33-<39$ & Baik \\
$\mathrm{Mi}-0,5 \mathrm{SDi}$ s/d Mi + 0,5 SDi & $27-<33$ & Cukup \\
$\mathrm{Mi}-1,5 \mathrm{SDi}$ s/d Mi - 0,5 SDi & $21-<27$ & Tidak baik \\
$\mathrm{Mi}-3 \mathrm{SDi} \mathrm{s} / \mathrm{d} \mathrm{Mi}-1,5 \mathrm{SDi}$ & $12-<21$ & Sangat tidak baik \\
\hline
\end{tabular}

Berdasarkan analisis data yang telah dilakukan, diperoleh nilai rata-rata kemampuan kerjasama dengan menerapkan model pembelajaran Snowball Throwing adalah 39 yang berada pada kelas interval $39-<48$ yang termasuk kategori sangat baik.

Data hasil post-test kemampuan kerjasama anak kelompok kontrol di TK Aisyiyah Singaraja menunjukkan bahwa nilai tertinggi adalah 35 dan nilai terendah adalah 22. Data rekapitulasi perhitungan skor kemampuan kerjasama anak pada kelompok kontrol menunjukkan bahwa nilai mean adalah 28,7 median 27,77 dan modus 24 . Sebaran data kemampuan kerjasama pada kelompok kontrol dapat dilihat pada tabel 3.

Tabel 3.

Ringkasan Hasil Statistik Kemampuan Kerjasama Kelompok Kontrol

\begin{tabular}{ll}
\hline Statistik Deskriptif & Hasil Post test Kelompok Eksperimen \\
\hline Mean & 28,7 \\
Median & 27,77 \\
Modus & 24 \\
Standar Deviasi & 5,28 \\
Varians & 27,87 \\
\hline
\end{tabular}

Berdasarkan tabel.3 diketahui bahwa modus lebih kecil dari median dan dan lebih kecil dari mean $(\mathrm{Mo}<\mathrm{Me}<\mathrm{M})$. Sehingga kurva berbentuk juling positif. Mengetahui kualitas variable kemampuan kerjasama anak kelompok kontrol dikonversikan berdasarkan penilaian skala lima untuk kelompok kontrol dapat dilihat pada tabel 4.

Tabel 4.

Konversi Skala Lima Hasil Post Test Kelompok Kontrol

\begin{tabular}{lll}
\hline \multicolumn{1}{c}{ Konversi } & \multicolumn{1}{c}{ Kelas Interval } & \multicolumn{1}{c}{ Klasifikasi/ Predikat } \\
\hline $\mathrm{Mi}+1,5 \mathrm{SDi}$ s/d Mi + 3 SDi & $39-<48$ & Sangat baik \\
$\mathrm{Mi}+0,5 \mathrm{SDi}$ s/d Mi + 1,5 SDi & $33-<39$ & Baik \\
$\mathrm{Mi}-0,5 \mathrm{SDi}$ s/d Mi + 0,5 SDi & $27-<33$ & Cukup \\
$\mathrm{Mi}-1,5 \mathrm{SDi}$ s/d Mi - 0,5 SDi & $21-<27$ & Tidak baik \\
$\mathrm{Mi}-$ 3SDi s/d Mi - 1,5 SDi & $12-<21$ & Sangat tidak baik \\
\hline
\end{tabular}

Berdasarkan analisis data yang telah dilakukan, diperoleh nilai rata-rata kemampuan kerjasama dengan menerapkan model pembelajaran Snowball Throwing adalah 28,7 yang berada pada kelas interval $27-<33$ yang termasuk kategori cukup. 
Uji prasyarat dilakukan sebelum uji hiotesis.Uji prasyarat dalam penelitian ini meliputi uji normalitas dan homogenitas hasil kemampuan kerjasama.Uji prasyarat dilakukan pada hasil posttest kelompok eksperimen dan pada kelompok kontrol. Kriteria pengujian data berdistribusi normal jika $x^{2}{ }_{\text {hitung }}<x^{2}$ tabel dengan taraf signifikansi $5 \%$ dan derajat kebebasan $\mathrm{dk}=$ (jumlah kelas parameter-1).

Uji normalitas sebaran data untuk skor pada lembar observasi siswa digunakan analisis ChiKuadrat. Rekapitulasi hasil uji normalitas dapat dilihat pada tabel 5.

Tabel 5.

Hasil Uji Normalitas Data Kelompok Eksperimen

\begin{tabular}{lccl}
\hline $\mathrm{N}$ & $x^{2}{ }^{\text {hitung }}$ & $x^{2}$ tabel & Kesimpulan \\
22 & 4,78 & 9,488 & Berdistribusi Normal \\
\hline
\end{tabular}

Hasil uji normalitas diperoleh harga $\mathrm{x}^{\wedge} 2$ hitung $=4,78$ dengan taraf signifikansi $5 \%$ dan derajat kebebasan $(\mathrm{dk})=\mathrm{k}-1=5-1=4$ diperoleh $x^{2}$ tabel $=9,488$, sehingga $x^{2}{ }_{\text {hitung }}<x^{2}$ tabel, dengan demikian diterima dengan kesimpulan bahwa data skor kemampuan kerjasama pada anak kelompok eksperimen berdistribusi normal.

Uji normalitas sebaran data untuk skor pada lembar observasi siswa digunakan analisis ChiKuadrat.Rekapitulasi hasil uji normalitas dapat dilihat pada tabel 6 .

Tabel 6.

Hasil Uji Normalitas Data Kelompok Kontrol

\begin{tabular}{lccl}
\hline $\mathrm{N}$ & $x^{2}{ }^{\text {hitung }}$ & $x^{2}$ tabel & Kesimpulan \\
20 & 2,833 & 9,488 & Berdistribusi Normal \\
\hline
\end{tabular}

Hasil Uji Normalitas kelompok kontrol diperoleh harga $x^{2}$ hitung $=2,833$ dengan taraf signifikansi $5 \%$ dan derajat kebebasan $(\mathrm{dk})=\mathrm{k}-1=5-1=4$ diperoleh $x^{2}$ tabel $=9,488$, sehingga $x^{2}{ }_{\text {hitung }}<x^{2}$ tabel, dengan demikian diterima dengan kesimpulan bahwa data skor kemampuan kerjasama pada anak kelompok eksperimen berdistribusi normal.

Berdasarkan analisis deskriptif telah diperoleh nilai dari Standar Deviasi (SD) dan varians dari kelompok eksperimen dan kelompok kontrol, yang disajikan pada Tabel 7.

Tabel 7.

Deviasi dan Varians Kelompok Eksperimen dan Kelompok Kontrol

\begin{tabular}{clll}
\hline \multicolumn{1}{c}{ Statistik } & Kelompok Eksperimen & & Kelompok Kontrol \\
Standar Deviasi (SD) & 8,9 & 5,28 & \\
Varians $(\mathrm{S})^{2}$ & 79,38 & 27,87 & \\
\hline
\end{tabular}

Hasil homogenitas data kemampuan kerjasama anak pada kelompok eksperimen dan kelompok kontrol dengan perhitungan uji fisher (uji f) diperoleh $F_{\text {hitung }}=2,84$. Selanjutnya $F_{\text {hitung }}$ dibandingkan dengan $F_{\text {tabel }}$ pada taraf signifikansi $5 \%$. Berdasarkan $F_{\text {tabel }}$ pada taraf signifikansi $5 \%$ dengan $\mathrm{df} 1=\mathrm{k}-1=2-1=1$, dan df2 $=\mathrm{n}-\mathrm{k}=42-2=40$, didapatkan harga $\mathrm{F}_{\text {tabel }}$ sebesar 4,08. Hasil tersebut menunjukkan Fhitung $<F_{\text {tabel, }}$, sehingga dapat disimpulkan bahwa kedua kelompok data homogen.

Berdasarkan uji prasyarat yang dilakukan yaitu uji normalitas dan uji homogenitas, diperoleh bahwa data hasil kemampuan kerjasama pada kelompok eksperimen dan kelompok kontrol adalah normal dan homogen. Dengan demikian dapat dilakukan uji hipotesis penelitian dengan rumus uji-t polled varians, karena jumlah sampel berbeda dan varian homogen. Kriteria untuk pengujian hipotesis adalah $\mathrm{H}_{0}$ diterima jika $\mathrm{t}_{\text {hitung }} \leq \mathrm{t}_{\text {tabel }}$ dan $\mathrm{H}_{0}$ ditolak jika $t_{\text {hitung }} \geq \mathrm{t}_{\text {tabel. }}$. Pengujian dilakukan pada taraf signifikansi $5 \%$ dengan $\mathrm{dk}=\mathrm{n}_{1}+\mathrm{n}_{2}-2$. Adapun hipotesis statistik yang diujikan yaitu $: \mathrm{HO}=$ Tidak terdapat pengaruh yang signifikan model pembelajaran Snowball Throwing terhadap kemampuan kerjasama pada anak taman kanak-kanak kelompok B di gugus VI Kecamatan Buleleng tahun pelajaran 2018/2019. Ha =Terdapat pengaruh yang signifikan model pembelajaran Snowball Throwing terhadap kemampuan kerjasama pada anak taman kanak-kanak 
kelompok B di gugus VI Kecamatan Buleleng tahun pelajaran 2018/2019.Rangkuman hasil analisis uji-t data post test kemampuan kerjasama dapat disajikan pada Tabel 8.

Tabel 8.

Rangkuman Hasil Analisis Uji-t

\begin{tabular}{|c|c|c|c|c|c|c|c|c|}
\hline No & Kelompok & $\mathrm{N}$ & Dk & $\mathrm{M}$ & Varians & $t_{\text {nitung }}$ & $t_{\text {htabel }}$ & Ket \\
\hline 1. & Eksperimen & 22 & \multirow{2}{*}{40} & 37 & 79,38 & \multirow{2}{*}{10,12} & \multirow{2}{*}{2,024} & \multirow{2}{*}{$\begin{array}{c}\mathrm{H}_{0} \text { ditolak dan } \\
\mathrm{H}_{1} \text { diterima }\end{array}$} \\
\hline 2. & Kontrol & 20 & & 28,7 & 27,87 & & & \\
\hline
\end{tabular}

Berdasarkan analisis data menggunakan uji-t diperoleh nilai $t_{\text {hitung }} 10,12$ sedangkan $t_{\text {tabel }}$ dengan taraf signifikansi $5 \%$ dan dk $(22+20)-2=40$ adalah 2,024 dengan demikian $t_{\text {hitung }} 10,12$ lebih besar dari pada $\mathrm{t}_{\text {tabel }}>2,024$ maka $\mathrm{H}_{0}$ ditolak dan $\mathrm{H}_{a}$ terima. Jadi dapat ditarik kesimpulan bahwa terdapat pengaruh yang signifikan model pembelajaran Snowball Throwingterhadap kemampuan kerjasama pada anak taman kanak-kanak kelompok B di gugus VI Kecamatan Buleleng tahun pelajaran 2018/2019.

Memberikan pembelajaran dengan model pembelajaran Snowball Throwingberpengaruh secara signifikan terhadap kemampuan kerjasama pada anak. Hal ini juga didukung secara empiris melalui penelitian eksperimen yang telah dilakukan.

Berdasarkan hasil temuan pada kedua kelompok diperoleh jika kedua kelompok yang awalnya memilikki kemampuan setara, lalu setelah diberikan perlakuan pada kelompok eksperimen maka perolehan nilai kemampuan kerjasama pada anak mengalami perbedaan yang signifikan.Kemampuan kerjasama pada anak kelompok eksperimen lebih baik apabila dibandingkan dengan kemampuan kerjasama pada anak kelompok kontrol.

Hal ini dapat dilihat juga dari rata-rata siswa kelompok eksperimen dan siswa kelompok kontrol.Perbedaan kemampuan kerjasama tersebut karena adanya pembelajaran dengan menggunakan model pembelajaran Snowball Throwing yang diterapkan pada kelompok ekspermen.

Hasill temuan dari penelitian ini menunjukkan bahwa model pembelajaran Snowball Throwingberpengaruh secara signifikan terhadap kemampuan kerjasama pada anak.Hal ini dikarenakan beberapa hal diantaranya model pembelajaran Snowball Throwingsangat memberikan kesempatan pada anak untuk aktif dan mau bertukar pengalaman dalam menyelesaikan permasalahan yang muncul dalam kelompok dan berlangsung secara lebih interaktif dan menyenangkan.Pembelajaran Snowball Throwingmembentuk suasana kelas menjadi dinamis dan anak menjadi aktif karena kegiatan yang dilakukan anak tidak hanya berpikir, namun anak juga di ajak menulis, berbicara, ataupun bertanya.Selain itu anak juga dapat belajar bertanggung jawab dan kerjasama. Hal ini sesuai dengan pendapat Akhiriyah (2011) "model pembelajaran Snowball Throwingakan menciptakan suasana yang menyenangkan dalam proses belajar dan membangkitkan semangat anak dalam belajar".

Pembelajaran dengan menggunakan model pembelajaran Snowball Throwingmengajak anak secara langsung untuk merumuskan pertanyaan dan memacahkan masalah dengan cara menjawab pertanyaan yang diberikan oleh lawan kelompoknya. Melalui hal tersebut anak dilatih untuk berdiskusi dan menghargai pendapat yang diberikan oleh teman kelompoknya. Hal ini sesuai dengan pendapat Syafitri (dalam Dewi, 2014) bahwa "model pembelajaran kooperatif tipe Snowball Throwingmerupakan salah satu modifikasi dari teknik bertanya yang memberikan kesempatan pada anak untuk merumuskan pertanyaan yang dimodifikasi dalam sebuah permainan yang menarik dengan melemparkan bola salju (Snowball Throwing) yang sudah berisi pertanyaan dari sesama teman anggota kelompok".

Pengalaman secara nyata (langsung) ini akan memberikan pengetahuan anak untuk membangun kemampuan dalam berinteraksi dalam kelompok, tanggung jawab. Hal ini sejalan dengan pendapat Suyanto (dalam Fauzidin, 2016) menyebutkan bahwa dalam kerjasama anak 
usia dini harus ada empat elemen dasar yaitu: saling ketergantungan yang saling menguntungkan pada anak dalam melakukan usaha bersama-sama, adanya interaksi langsung antara anak dalam satu kelompok, masing-masing anak mempunyai tanggung jawab untuk bisa menguasai materi yang diajarkan, menggunakan kemampuan interpersonal dan kelompok kecil secara tepat yang dimiliki setiap anak.

Model pembelajaran Snowball Trhowing dapat digunakan secara efektif untuk mengembangkan kemampuan kerjasama sebab model pembelajaran Snowball Trhowing mengajak anak agar mampu menyesuaikan diri, menjalin hubungan dengan teman kelompok dan memiliki tanggung jawab.

Lain halnya dengan pembelajaran pada kelompok eksperimen, kegiatan pembelajaran yang berlangsung pada kelompok kontrol masih kurang optimal. Hal ini dikarenakan pembelajaran hanya berpusat pada guru atau dengan kata lain, guru sebagai sumber ilmu dan pemberi informasi yang mutlak. Pembelajaran yang demikian membuat anak, mudah jenuh, mengantuk dan pasif. Selain itu, keadaan anak-anak pada saat proses pembelajaran berlangsung terlihat kurang aktif jika dibandingkan dengan kelompok eksperimen. Pada kelompok kontrol anak-anak kurang diberi kesempatan untuk melakukan kegiatan kelompok yang berkaitan dengan kerjasama.Kegiatan anak-anak lebih banyak pada kegiatan individu seperti mengerjakan LKA dan mewarnai.Sehingga dengan begitu perkembangan anak kurang terstimulasi terutama kemampuan kerjasama.

\section{PENUTUP}

Berdasarkan uraian tersebut, pembelajaran menggunaka model pembelajaran Snowball Throwing pada penelitian ini memiliki keunggulan yakni dapat menumbuhkan rasa tanggung jawab, menjalin hubungan dengan teman dan meningkatkan interaksi sosial dengan teman sebaya.Model pembelajaran Snowball Throwing juga efektif dalam memicu semangat dan aktif dalam mengikuti semua pembelajaran di dalam kelas, maupun di luar kelas serta dapat membuat anak mampu untuk menyampaikan pendapatnya maupun menerima pendapat teman-temannya.

Berdasarkan hasil penelitian dapat disimpulkan bahwa ada peningkatan kemampuan kerjasama pada anak dikelas eksperimen sesudah diberikan perlakuan sebanyak 10 kali perlakuan.Oleh sebab itu dapat disimpulkan bahwa ada pengaruh yang signifikan model pembelajaran Snowbal Throwing terhadap kemampuan kerjasama pada anak Taman kanak-kanak kelompok B di gugus VI Kecamatan Buleleng tahun pelajaran 2018/2019.

Keterbatasan penelitian ini pertama terletak pada waktu bermain anak yang pendek sedangkan model pembelajaran Snowball Throwing ini memerlukan waktu yang cukup lama untuk mencapai keutuhan pembelajaran.Kedua, hubungan model pembelajaran Snowball Throwing dengan beberapa kemampuan kerjasama yang beu terstimulasi dengan baik tidak mampu diulas secara utuh dalam penelitian ini.Hal inilah yang menjadi tinjauan pengembangan penelitian berikutnya terkait kemampuan kerjasama anak melalui model pembelajaran Snowball Throwing.Dengan demikian bidang atau kemampuan tertentu yang kurang dikuasai dapat distimulasi agar lebih terampil.

Saran yang dikemukakan dalam penelitian ini antara lain guru dapat menggnakan dan memberikan kesempatan yang luas bagi anak untuk bermain melalui model pembelajaran Snowball Throwing dengan model-model yang sifatnya aplikatif sehingga pembelajarannya menyenangkan dan memberikan pengalaman yang lebih bermakna yang akan mengajak anak mendapatkan pengalaman secara langsung yang akan meningkatkan kemampuan kerjasamanya. Dan saran bagi peneliti selanjutnya yaitu meneliti kembali aspek yang masih rendah seperti kemampuan yang berkaitan dengan kemampuan social melalui model pembelajaran Snowball Throwing.

\section{DAFTAR PUSTAKA}

Agung, A. A. G. 2014. Metodologi Penelitian Pendidikan. Malang:Aditya Media Publishing.

Akhiriyah, D. Y. 2011. "Penerapan Model Pembelajaran Snowball Throwing Untuk Meningkatkan Kualitas Pembelajaran Ips Pada Siswa Kelas V Sdn Kalibanteng Kidul 01 Kota Semarang 
(Aplicating Snowball Throwing Model For Improving The Social Intructional At Fifth, Sdn Kalibanteng Kidul 01 Kota Semarang)".Volume 1, Nomor 2.

Candiasa, I Made. 2011. Pengujian Instrumen Penelitian Disertai Aplikasi Iteman dan Bigsteps.Singaraja : Undiksha Press.

Emzir. 2014. Metode Penelitian Pendidikan. Jakarta: Rajawali Press.

Faidho, A. 2016.“Pengaruh Model Pembelajaran Snowball Throwing Bermedia Kartu Bergambar Terhadap Kemampuan Membaca Permulaan Anak Kelompok B".Jurnal PAUD Teratai.Volume 05 Nomor 03.

Fauzidin. 2016. "Peningkatan Kemampuan Kerja Sama melalui Kegiatan Kerja Kelompok Pada Anak Kelompok A TK Kartika Salo Kabupaten Kamar". Jurnal Paud Tambusai. Volume 2 Nomor 1.

Mulyasa. 2017. Manajemen PAUD. Bandung: PT Remaja Rosdakarya.

Nugraha, Ali dan Yeni Rachmawati.2015. Metode Pengembangan Sosial Emosional.Kementrian Riset, Teknologi dan Pendidikan Tinggi : Universitas Terbuka.

Peraturan Mentri Pendidikan dan Kebudayaan Republik Indonesia Nomor 137 Tahun 2014.

Sugiyono. 2010. Metode Penelitian Kuantitatif Kualitatif dan R\&D. Bandung: Aflabeta Bandung.

Sugiyono. 2015. Metodologi Penelitian Pendidikan. Bandung: Alfabeta.

Sujiono, Y N. 2009. Konsep Dasar Pendidikan Anak Usia Dini. Jakarta : PT Indeks.

Undang-Undang Nomor 20 Tahun 2003.Sistem Pendidikan Nasional.

Susanto, Ahmad. 2011. Perkembangan Anak Usia Dini (Pengantar dalam Berbagai Aspeknya). Jakarta: Kencana Prenada Media Group.

Tedjasaputra, M. S. 2005. Bermain, Mainan dan Permainan.Jakarta : PT Gramedia Widiasarana Indonesia. 